6.

Derecho del entorno 



\title{
The Protection of Biomes and the International Commitments AND THE NeW LAW BRAZILIAN Forest
}

[La protección del bioma y los acuerdos internacionales en el nuevo Derecho forestal brasileño]

\author{
Maria Luiza Machado Granziera* \\ Catholic University of Santos, São Paulo, Brazil \\ FERNANDo ReI** \\ Catholic University of Santos, São Paulo, Brazil
}

\begin{abstract}
Abstrac
The Brazilian Forest Code, a national law that protects all kinds of vegetation, should contribute, in any sense, to the achievement of the objectives of the Conventions on Biological Diversity. Currently, the rapid expansion of the agricultural frontier over the forests, mainly in the Amazon Biome and the Cerrado, aims towards the cultivation of soya and sugar cane. These cultures increase economic development of Bra-
\end{abstract}

\section{RESUMEN}

El nuevo Código Forestal de Brasil, una ley nacional que protege a todos los tipos de vegetación, debería contribuir de alguna manera al logro de los objetivos de la Convención sobre la diversidad biológica y de la Convención sobre el cambio climáti$c o$. En la actualidad, la rápida expansión de la frontera agrícola sobre las florestas y los bosques, principalmente en el Amazonas y el Cerrado, apunta hacia el incremento del cultivo de la soja y la caña de azúcar.

RECIBIDO el 5 de abril y ACEPTADo el 4 de junio de 2013

* Professor of the Doctoral/PhD Program in International Environmental Law, at Catholic University of Santos, São Paulo, Brazil. Rua Agrário de Sousa, 75, São Paulo, SP CEP 01445010, Brasil. marialuiza.granziera@gmail.com

** Professor of the Doctoral/PhD Program in International Environmental Law, at Catholic University of Santos, São Paulo, Brazil. Scientific Director of Brazilian Society of International Environmental Law. Rua São Carlos do Pinhal, 640 \# 71, São Paulo, SP CEP 01333-000,Brasil. fernandorei@ig.com.br 
zil besides being considered sources of renewable energy. Otherwise, the pressure for more room for agribusiness has impacted on the environment severely. As a consequence, the Brazilian Forest Code has been reviewed, to minimize the obligations concerning forest protection. The proposed changes might undermine the fulfillment of obligations assumed by Brazil in the Convention of Biological Diversity and in the Convention on Climate Change, since the deforestation destroys the biodiversity and generates greenhouse gases.

KeYwords
Biomes - Biodiversity - Climate
Change - Forest Law.

\section{KEYWORDS} Change - Forest Law.
Estas culturas incrementan el desarrollo económico de Brasil y la segunda, por medio del etanol, es considerada fuente de energía renovable. Existe una continua presión de la agro-industria para obtener más espacio para la producción sin considerar los impactos severos sobre el medio ambiente. Como consecuencia de ello, el antiguo Código Forestal brasileño ha sido revisado, para reducir al mínimo las obligaciones relativas a la protección de las florestas y de la vegetación protegida, en general. Los cambios propuestos podrán poner en riesgo el cumplimiento de las obligaciones asumidas por Brasil en el ámbito de la CDB y de la CCC, ya que la deforestación destruye la biodiversidad y genera gases de efecto invernadero.

Palabras clave

Biomas - Biodiversidad - Cambio climático-Derecho Forestal.

\section{INTRODUCTION}

Brazil, a country gifted with important biological diversity, is one of the last holdouts that still has forests and other native vegetation contributing decisively to the climate balance and biodiversity protection, topics included in the international agendas considering their importance regarding maintenance of life on the planet.

The main Brazilian biomes (Amazon, Atlantic Forest, Cerrado, Caatinga, Pampa and Pantanal) besides having different characteristics, contribute strongly to biodiversity, which deserve special care from entrepreneurs who develop activities in these areas, to prevent destruction and environmental losses.

On the other hand, Brazil has been growing economically, and now occupies an important position in worldwide economy. In the social sphere, it is trying to reduce the abyssal differences in income distribution, which allows the arrival of millions of people to a market previously unachievable. One of the factors of Brazilian economic growth is the agricultural activity, mainly soybean and sugarcane monocultures and the cattle breeding in pastures.

It is true these crops are biofuel raw materials, therefore, important factors for sustainable development, replacing oil, whenever possible. In 
this sense, it is recommendable to search for renewable energy resources. It occurs that some areas wanted for new ventures are precisely located in unexplored regions, i.e. in the biomes mentioned above.

It is remarkable that all this development refers to the mere production of commodities - grains and meat without adding value- which requires the production of huge quantities to make the business feasible and profitable, since the unit prices are low, compared to manufactured goods. Hence the enormous pressure faced by the country to open up new fields of agricultural and livestock production.

Thus, we question the legitimacy of this development, based on activities of monoculture and extensive livestock at the expense of other values protected by the Brazilian Constitution, regarding to the rights to an ecologically balanced environment and the protection of essential ecological processes and healthy quality of life as well as the right to work.

The question that arises refers to the limits of sustainability of these activities, since protection of biomes imposes limits to this ambiguous development, mainly socially. In general, the commodities production do not requires neither specialized nor constant labor force, imposing wages far below the needs required by the people involved in these services. This development is founded in activities of monoculture and extensive livestock, in detriment of other values protected by the Brazilian Constitution, regarding to everyone's right to an ecologically balanced environment and the protection of essential ecological processes, healthy quality of life as well as the right to work.

In order to legitimize this unprecedented advance in areas still covered with native vegetation, the Forest Code was replaced by a law that significantly reduces the protection of ecosystems and biomes ignoring, besides the Constitution, commitments made by Brazil, regarding biodiversity and climate change in international treaties.

The purpose of this article is to characterize the Brazilian biomes, demonstrating their diversity and importance, describing the advance of agriculture and livestock in the country during centuries, pointing out the main changes that the new Forest Act sets to minimize forest and biodiversity protection and finally enhance the commitments Brazil is failing to fulfill, with the new law regarding forests.

\section{Brazilian Biomes: Characteristics AND OCCUPATION}

\section{Amazon.}

Located in the northern part of Brazil, the Amazonian ecosystems occupy 4.196 .943 square $\mathrm{km}$, which corresponds to $49.29 \%$ of the Brazilian 
territory ${ }^{1}$. The Amazon is recognized as the largest tropical rainforest and the largest gene bank in the world, with one third of the reserves of tropical rain forests. $20 \%$ of the freshwater available in the world, flows in the Amazon, which also has a mineral asset not yet completely measured. Amazonian ecosystems are carbon sinks, contributing to global climate balance. In this scenario, there is a delicate balance in the relationship of biological populations that are sensitive to anthropogenic interference.

The forest, despite being the most determining characteristic of the Amazon, does not hide the wide variety of other ecosystems, among which are dry land forests, flooded forests, wetlands, open fields and savannas. As a result, the Amazon is home to countless plant and animal species: 1.5 million species cataloged, 3,000 fish species, 950 types of birds, and even insects, reptiles, amphibians and mammals ${ }^{2}$.

The massive exploitation of the Amazon began in the 60s and 70s, inspired by the need to occupy the territory of northern Brazil. However, the occupation has adopted standards that were used in the south of the country, based on the destruction of forests for planting without any attention to local natural resources, unsuitable for this biome. Currently, $17 \%$ of the Amazon has been mischaracterized.

\section{Atlantic Forest.}

Brazil was and still is mainly inhabited in the Coastal Zone, a strip of approximately 8,500 kilometers. About $25 \%$ of the Brazilian population live in this area, corresponding to 42 million people. According to the Brazilian Institute of Geography and Statistics - IBGE, the Atlantic Forest biome, located in the Coastal Zone, occupies $1,110,182$ square $\mathrm{km},(13.04 \%$ of the Brazilian territory $)^{3}$ and has experienced the consequences of human presence before the other biomes. During the agricultural frontier expansion, in search of new spaces for economic activities, particularly agriculture and extensive cattle breeding, other biomes were impacted. The logic that predominates in Brazil is still the clearing of untouched areas, customarily adopted during the colonial period. This trend remains, even after the evidence of the

${ }^{1}$ IBGE Releases Map of Biomes of Brazil and the Vegetation Map of Brazil, to celebrate World Biodiversity Day, available in: http://saladeimprensa.ibge.gov.br/noticias ?view $=$ noticia\&id $=1 \&$ busca $=1 \&$ idnoticia $=169$ [access on 5 of April 2013]. http:// www.ibge.gov.br/home/presidencia/noticias/noticia_visualiza.php?id_noticia $=169$ [access on 25 of October 2012].

${ }^{2}$ IBAMA, Brazilian Biomes. Amazon, available in: http://www.ibama.gov.br/ecossistemas/amazonia.htm [access on 25 of October 2012].

${ }^{3} I B G E$. , cit. (n. 1), 
need to protect ecosystems through sustainable economic activities which protect the environment and improve the quality of life.

Because the Atlantic Forest stretches throughout the coast of Brazil, it has diverse ecosystems due to differences in soil, topography and climate characteristics. It originally occupied $14 \%$ of the Brazilian territory. Currently only $7.3 \%$ of the original forest remains untouched. However, it still has 261 species of mammals, 620 birds, 200 reptiles and 280 amphibians, and 567 species only occur in this biome. It also has about 20 thousand species of vascular plants, of which only 8000 of them only occur in the Atlantic Forest. In the south of the state of Bahia, the world's largest botanical diversity for woody plants, i.e. 454 species, was identified recently; this was registered in a single hectare. The water bodies located in the Atlantic Forest provide water for $70 \%$ of the Brazilian population ${ }^{4}$.

The exploration of the Atlantic Forest has been occurring since the arrival of the Portuguese in Brazil, in the 16th century and began with the exploration of pau brasil wood. The process of deforestation continued during the sugar cane (Northeast), gold (Minas Gerais), coffee (São Paulo) and pastures cycles. Simultaneously, a strong process of urbanization occurred in the twentieth century, with the rise of large cities, such as Sao Paulo, Rio de Janeiro and Belo Horizonte which, along with other cities, formed metropolitan areas with millions of inhabitants, with no planning or control.

\section{Caatinga.}

The Caatinga biome is the major ecosystem in the Northeast (Piauí, Ceará, Rio Grande do Norte, Paraíba, Pernambuco, Sergipe, Alagoas, Bahia, Maranhão), extending as far as Minas Gerais (Southeast). It occupies 9.92\% of the Brazilian territory, corresponding to 844,453 square $\mathrm{km}^{5}$. Located in an area of semi-arid climate, it has a great variety of landscapes and is dominated by vegetation types with xerophytic characteristics - dry vegetation, which make up a warm, rugged landscape, interspersed with species such as cacti and bromeliads.

The Caatinga is unique: although located in a semi-arid climate area, it presents great landscape variety that includes biological richness and endemism. The fauna surveys made in the Caatinga area reveal the existence of 40 species of lizards, seven species of anfibenídeos (lizards with no legs), 45 species of snakes, four turtles, one of Crocodylia, 44 frogs and a Gymnophiona ${ }^{6}$.

${ }^{4}$ IBAMA, Brazilian Biomes. Atlantic Forest, available at: http://www.ibama.gov. $\mathrm{br} /$ ecossistemas/mata_atlantica.htm [access on 25 of October 2012].

${ }^{5}$ IBGE, cit. (n. 1).

${ }^{6}$ IBAMA, Biomas Brasileiros. Caatinga, available at: http://www.ibama.gov.br/ ecossistemas/caatinga.htm [access on 25 of October 2012]. 
This biome has been changing and native plant species are being replaced by crops and pastures. Deforestation and forest burning are still common practices in preparing the land for agriculture besides destroying the vegetation, and affecting the maintenance of wildlife populations, water quality and balance of the climate and soil. 27 million people currently live in this biome. Approximately $80 \%$ of the original area has been affected by human activities.

\section{Cerrado.}

The Cerrado biome is typical of Brazilian Central Plateau, in the states of Goiás, Tocantins, Mato Grosso, Mato Grosso do Sul, part of Minas Gerais, Bahia and Distrito Federal. The land in this area is usually "flat, characterized by small trees and spaced shrubs, associated with grass" ${ }^{7}$ Cerrado occupies $23.92 \%$ of the Brazilian territory, corresponding to 2,036,448 square $\mathrm{km}^{8}$.

The biome contains two layers: an upper, formed by trees and shrubs endowed with deep roots that allow them to reach the water table, located between 15 and 20 meters, and a lower one, composed of a carpet of creeping grasses, with little roots deep. In the dry season, the ground cover -dry grass- favors the spread of fires, which sometimes occur in parks located in this biome. The tortuous aspect of vegetation ins't due not to lack of water, but to the imbalance of nutrients.

According to the Brazilian Institute of Environment and Renewable Natural Resources (IBAMA), the Brazilian Cerrado savanna is recognized as the world's richest biome in biodiversity, with the presence of various ecosystems, with more than 10,000 species of plants, with 4,400 endemic (unique) to this area. The fauna has 837 bird species, 67 species of mammals, covering 161 species and 19 endemic, 150 species of amphibians, 45 of them endemic, 120 species of reptiles, 45 of them endemic; only in the Federal District there are 90 species of termites, a thousand species of butterflies and 500 species of bees and wasps?

From the $60 \mathrm{~s}$ on, ecosystems located in the Cerrado began to give place to the expanding agricultural frontier -soya, rice, wheat and livestock- using deforestation and forest burning to clear up spaces and chemical fertilizers and pesticides to ensure productivity. This kind of unsustainable use has caused erosion, rivers siltation and poisoning of the ecosystems, leaving only $20 \%$ of the original biome.

${ }^{7}$ Moreira, Iara Verocai Dias, Vocabulário básico de meio ambiente (Rio de Janeiro, Fundação Estadual de Engenharia do Meio Ambiente, 1990), p. 51.

${ }^{8}$ IBGE. , cit. (n. 3).

${ }^{9}$ IBAMA, Brazilian Biomes. Cerrado, available in: http://www.ibama.gov.br/ecossistemas/cerrado.htm [access on 1 of October 2012]. 


\section{Pampa.}

The Pampa Biome includes the "pampa", an indigenous term meaning "flat region", mostly found in the southern state of Rio Grande do Sul, reaching out to Uruguay and Argentina. It also includes the "fields on mountain tops", located in transition areas, where pines and fields similar to the savanna are predominant. It occupies $2.07 \%$ of the Brazilian territory, corresponding to 176,496 square $\mathrm{km}^{10}$.

The pressure of herding and the fire practice harm the growth of vegetation, and in some areas the phenomenon of desertification, with soils with low fertility and very susceptible to erosion, is already evident.

The techniques used in continuous and extensive herding, without the necessary care to recover and maintain vegetation, associated with the practice of fire, are exposing the biome to serious risks of degradation, mainly because the consequences of these uses remain unknown.

Other important economic activities, based on the use of fields, such as rice, corn, wheat and soybean are often grown in association with cattle and sheep. In certain areas, the expansion of soy and wheat caused the disappearance of fields and woods. Currently, these two cultures virtually occupy the entire area, causing a gradual decline in soil fertility. This also results in erosion, soil compaction and loss of organic matter. The Biome has been destroyed in $54 \%$.

\section{Pantanal.}

Pantanal is "the largest wetland in the world". Its geographical location has particular relevance, since it represents the link between the Cerrado in central Brazil, Chaco in Bolivia, and the Amazon region in the north, with the Upper Paraguay basin. Pantanal occupies 1,76\% of the Brazilian territory, corresponding to 150,355 square $\mathrm{km}^{11}$.

Low, medium and high flood plains occur in this area, which has high biological productivity, high density and diversity of wildlife.

Environmental problems of the Pantanal are not local, but come from activities that take place beyond its territory, causing pollution and degradation: diamond and gold mining, hunting, fishing, tourism, predatory agriculture, the construction of highways and hydroelectric plants.

Due to the advance of the agricultural frontier, which began in the 70 's, the vegetation of the Brazilian Highlands gave way to agriculture, imposing deforestation of vast areas of the plateau for the implementation of soybean, rice, and pastures. Inappropriate agricultural management resulted, among

\footnotetext{
${ }^{10}$ IBGE, cit. (n. 1).

${ }^{11}$ IBGE, , cit. (n. 1).
} 
other factors, in soil erosion and siltation of several rivers. The problem has been aggravated by the pollution of rivers with fertilizers and biocides. As a result of this development, cities located in the states of Mato Grosso and Mato Grosso do Sul also grew with no planning nor adequate infrastructure, especially regarding the sewage treatment, therefore polluting the Pantanal plain.

The exploitation of gold and diamonds near the city of Cuiabá and the headwaters of the Paraguay and São Lourenço rivers has attracted thousands of prospectors, whose activity causes the contamination of the water with mercury, sedimentation and compromises the biological productivity of streams and rivers.

Population growth has not occurred within the limits of the Pantanal, as its agrarian structure of large estates, keeps the cattle in flooded areas. However, due to the growth of its surroundings, $17 \%$ of the biome has been destroyed.

According to WWF, Pantanal is home to 4700 species of animals and plants. Among the surveyed species are 3500 plants (trees and vegetation aquatic and terrestrial), 325 fish, 53 amphibians, 98 reptiles, 656 birds and 159 mammals.

\section{The Basis of Environmental Protection in Brazil}

Law $\mathrm{N}^{\circ}$ 6.938/1981, which established the National Environmental Policy, represents a milestone in the treatment of human activities in the country, establishing a new legal relationship between economic development and environmental protection.

The fundamental objective of the Brazilian environmental policy is "to preserve, enhance and restore environmental quality propitious to life, focusing to ensure conditions for socioeconomic development, interests of national security and protection of the dignity of human life".

Important innovations were introduced in Brazilian law, adapting traditional legal institutions to the specificities of the environmental policy, such as objective liability for environmental damage, entitlement to sue for environmental damage persons other than the victim, as well as the innovative principles such as the participation of society in making decisions, the polluter-pays principle and the economic focus of the environment through economic instruments of management.

The law has set principles, objectives, guidelines, tools, and the National System of Environment responsible for the implementation of the environmental policy, highlighting: $i$ ) government action in maintaining the ecological balance, considering the environment as a public asset to 
be protected and assured, considering the collective use; $i i)$ rational use of the soil, subsoil, water and air; iii) planning and control of the use of environmental resources; iv) protection of the ecosystem, with preservation of representative areas; $v$ ) incentives to study and research technologies aimed at the rational use and protection of environmental resources; $v i$ ) monitoring environmental quality ${ }^{12}$.

The preservation and restoration of environmental resources and their rational use for present and future generations, as well as the compatibility of economic and social development with the preservation of the quality of the environment and ecological balance are key objectives of the National Policy of the Environment regarding sustainable development.

In 1988, the Constitution reaffirmed the principles and guidelines established by the National Environmental Policy, bringing environmental issues to a constitutional level. Brazilian environmental law is based, therefore, on the "everyone's right to an ecologically balanced environment". As an asset of common use and essential to a healthy quality of life, the duty to defend and preserve the environment for present and future generations is imposed upon both Government and society ${ }^{13}$.

According to the Constitution, "the economic order, based on the value of human labor and free enterprise, aims to assure dignified existence for all, according to the principles of social justice". The defense of the environment, which includes different treatments according to the impacts caused by each individual activity, is one of the principles to be observed in the conduct of the economic order ${ }^{14}$. The preservation and restoration of essential ecological processes are actions attributed to Government Authorities, to assure the effectiveness of the law. ${ }^{15}$.

According to the IUCN: "the essential ecological processes are governed, supported or strongly affected by ecosystems, essential for food production, health and other aspects of human survival and sustainable development. It is, for example, protective forests watersheds of coastal wetlands. The maintenance of such processes is vital to all societies, whatever their level of development"16.

From 1988, the actions related to the control of human activities have been structured, seeking a balance between economic activities and envi-

${ }^{12}$ Law $\mathrm{N}^{\circ} 6.938 / 81$, article $2^{\circ}$.

${ }^{13}$ Constitution, article 225.

${ }^{14}$ Constitution, article 170, VI.

${ }^{15}$ Constitution, article 225, $\$ 1{ }^{\circ}$, I.

${ }^{16}$ IUCN, Global Strategy for Conservation: Conservation of Living Resources for Sustainable Development (São Paulo, CESP, 1984), II. 
ronmental protection. Recently, social policies focused the development of people are a fact in Brazil.

The law enforcement in Brazil is still a difficult. This is reflected in the environmental field, especially regarding deforestation which has been taking place since colonial times. As the country is too large, there are still remains of the original biomes. But this cannot last forever. Although there is currently a tendency to reverse the disobedience to the law, the pressure of agribusiness, especially in Congress, is gradually legalizing deforestation and destruction of biomes. The current Law on the Protection of Forests is an example of this movement.

This paper will analyze some of the major changes that have occurred in the law, demonstrating the legalization of deforestation. We cannot measure the size of areas yet to be destroyed, to give way to agribusiness and livestock extension. The Permanent Preservation Areas (APP) and Legal Reserves will be the object of analysis, for its importance to the protection of biodiversity, to the soil, to the water resources and, consequently, to the preservation of Brazilian biomes.

\section{The Permanent Preservation Areas AND the Legal Reservation In THE New Forest ACT}

The former Forest Code established several limitations to the right of ownership towards the protection of ecosystems and biodiversity. The Permanent Preservation Areas (APP) and the Legal Reserves are examples of such limitations.

For decades, the former Forest Code was not always obeyed, with practically no concern by Government Authorities. In July, 222008 a presidential decree $^{17}$ imposed heavy fines on environmental laws violators, concerning APP and Legal Reserves protection. This action started a political movement, which focused changes in the Forest Code, and ended up in the publication of a new Brazilian Forest Act, which amended, among other issues, the protection of APP and Legal Reserve.

In this sense, it is important to emphazise that the new forest law defines, as consolidated rural area: "the area of rural property or possession which was occupied by people since July 22, 2008, containing buildings, improvements or agroforestry activities [...]"18. Therefore, according to the law, all destruction of APP or Legal Reserves which took place before that date is not considered a violation. The law established, in these cases, the charac-

\footnotetext{
${ }^{17}$ Decree No 6.514/2008.

${ }^{18}$ Law No $12.651 / 12$, article $3^{\circ}$, IV.
} 
terization of "consolidated rural area", not likely to undergo penalties. This means a recognition that the current law before that date was not respected and the government omitted it.

The changes consist of minor details of how the law must be implemented and do not clearly express the government's decision to promote the legalization of deforestation. In opposition, the new Forest Law establishes, in general, rules based on protection and sustainable use of forests plus other forms of native vegetation, in harmony with economic development, according to the following principles: $i$ ) recognition of forests as assets of common interest to all inhabitants of the country; ii) statement of Brazil's commitment to preserve its forests and other forms of native vegetation and biodiversity, soil and water resources, and the integrity of the climate system, focusing on the well-being of present and future generations; iii) recognition of the strategic role of rural production in the recovery and maintenance of forests and other forms of native vegetation, and the role of sustainability in agricultural production; $i v$ ) consecration of the country's commitment to environmental sustainable development model, which combines the productive use of land to the contribution of collective services of forests; $v$ ) governmental action for protection and sustainable use of forests; vi) common responsibility of Union, States, Federal District and Municipalities, as well as society, in creating policies for the preservation and restoration of native vegetation and its ecological and social functions in urban and rural areas; vii) fostering innovation for sustainable use, restoration and preservation of forests and other forms of native vegetation; and viii) creation and mobilization of legal and economic incentives to promote preservation and restoration of native vegetation, and the development of sustainable productive activities.

All these beautiful words, however, are meaningless as the new law deconstructs environmental protection through small loops that actually allow deforestation. In this paper it is impossible to analyze all the amendments made to the legislation, because of its length and complexity. The issues focused here are the most important changes imposed in the Permanent Preservation Areas and in the Legal Reserves.

\section{Permanent Preservation Areas.}

The Permanent Preservation Areas are protected spaces, covered or not by native vegetation, with the environmental function of preserving water resources, landscape, geological stability, biodiversity, facilitate gene flow of fauna and flora, soil protection and ensure well-being of human populations. This definition remained in the new law ${ }^{19}$.

${ }^{19}$ Law No $12.651 / 12$, article $3^{\circ}$, II. 
The APP areas were previously established by the former law in: $i$ ) the width of river and lakes (natural or artificial) banks in proportion to the width of the water body; ii) $50 \mathrm{~m}$ range around springs; $i i i$ ) hillsides with slopes over $45^{\circ}$, equivalent to $100 \%$ of maximum gradient on line; $i v$ ) salt marshes, such as fixing dunes and mangroves; $v$ ) edges of flat lands or plateaus; $v i$ ) in ridge lines; vii) altitudes above $1,800 \mathrm{~m}$; vii) tops of hills.

This APP definition was intended precisely to protect ecosystems and fragile environmental and soil conditions, always focusing the protection of people and the environment, especially biodiversity, ensuring the existence of ecological corridors. The law uses the expression "environmental function" for the APP. The function operates over objects, but its finality ins the environmental balance and protection ${ }^{20}$. Indeed, the the protection of the vegetation isn't a simple idea. Only the relation between the forest, the soil and the ecosystems which develop in that space assures the fulfillment of of its function. Without forest, there is no environmental function ${ }^{21}$.

The first amendment to mention is concerning the change in the criterion for the delimitation of APPs on river banks. According to the former law, the width of the strip to be protected was measured from its highest level, i.e., the level achieved during the seasonal watercourse perennial or intermittent flooding". Thus, the strip, designed to ensure environmental protection, remained intact even during the rainy season.

Presently, the calculation of the width of the river banks is made from the edge of the regular riverbed ${ }^{22}$, i.e. the riverbed where the water regularly runs throughout the year ${ }^{23}$. Therefore, in times of flood, when the level of the river rises, part of the range of APP is submerged, with the possibility of damaging vegetation intended for environmental protection. "This might be just a tiny difference. However, if this reduction is multiplied by 5.7 million farms in existence in Brazil, not including possessions uncounted for, and that many of these properties are estates of thousands acres, this could mean the destruction of remaining forests in million hectares in Brazil"24. The

\footnotetext{
${ }^{20}$ Benjamin, Antonio Herman Vasconcelos, Environmental Function, in Environmental Damage: Prevention, Recovery e Repression (São Paulo, Revista dos Tribunais, 1993), p. 60.

${ }^{21}$ GranZIERA, Maria Luiza Machado, Environmental Law (2 ${ }^{\text {nd }}$ edition, São Paulo, Atlas, 2011), p. 451.

${ }^{22}$ Law No $12.651 / 12$, article $4^{\circ}$, I.

${ }^{23}$ Law $\mathrm{N}^{\circ} 12.651 / 12$, article $3^{\circ}$, XIX.

${ }^{24}$ Magalhães, Vladimir Garcia, The Forest Code and the Global Warming, in Lavratti, Paula - Buzelato Prestes, Vanêsca, Law and Climate Changes, Forest Code Revision: Juridical Limitations (São Paulo, Instituto o Direito por um Planeta Verde, 2010) p. 59. Available at: http://www.observatorioeco.com.br/wp-content/ uploads/up/2010/12/cadigo-florestal.pdf [access on 25 of October 2012].
} 
replacement of the widest riverbed for the regular one, to set the APP, put at stake extensive wetlands throughout the country, specially in the Amazon and the Pantanal, which are important for biodiversity conservation, maintenance of water quality and quantity, and the provision of environmental services, as they protect human lives and public and private property from environmental disasters.

The former law protected all kinds of sources, even the intermittent and the waterholes, in a range of at least 50 meters wide, regardless of topography. The new law excluded the intermittent sources from being protected.

The new law also imposed new conditions for the use, protection and management of the APP. As an example, it allows, in small rural family properties or possessions ${ }^{25}$, short cycle seasonal crops in the strip of land exposed during the low tide of rivers or lakes, as long as they do not involve suppression of new areas of native vegetation and preserve the quality of the water and soil as well as protect wildlife.

The issue that arises in this type of legal provision is that the control of law enforcement has become more difficult. In the past, to see if there was vegetation or not in the APP was enough. With the new law, it became much more complex because it must be analyzed, from a culture implemented on the river banks, whether native vegetation has been removed or not, or whether there had been indeed native vegetation prior to the culture developed. Considering the size of the country, this rule will not be fully applied, unless the use of satellite systems for registering areas that still retain bushland in APP is adopted. Without this control, the native forest that currently exists will be quickly replaced by temporary and seasonal low tide short cycle crops, as permitted by the law.

The former Code provided exceptions to the protection of APP, authorizing the removal of vegetation in these areas to attend the hypothesis of: i) social interest (i.e.: agroforestry activities, erosion control etc.); ii) public services (i.e.: transport, infrastructure works, sanitation, telecommunications and energy); iii) low environmental impact (i.e. docks).

According to the former law, the vegetation that protects sources could not be suppressed to give way to ventures related to public services. Presently, this protection is no longer enforced ${ }^{26}$, and therefore, the production of water in certain areas is at stake.

The new law added, to the original list of the public services that allow the suppression of vegetation in APP, the facilities required to carry out

${ }^{25}$ Law No $12.651 / 12$, article 5, V: "Small rural family ownership or possession: the one exploited by the personal work of family farmers and rural entrepreneurs family, including settlements and agrarian reform projects".

${ }^{26} \mathrm{Law} \mathrm{N}^{\circ} 12.651 / 12$, article $8^{\circ}, \$ 1^{\circ}$. 
state, national or international sport competitions. This evidently clearly refers to World Cup (2014) and Olympiad (2016). Such events, although of extreme importance, must not affect Brazilian biodiversity, as their duration is short.

The salt marshes and mangroves are recognized as APP by the new law. However, the removal of native vegetation from these areas is permitted for the housing constructions and urbanization projects, included in projects of social interest in urban consolidated areas, occupied by low-income population, where the ecological function of mangrove has already been compromised $^{27}$. What this rule means is that there is no hope to recover those areas designated to protect water, soil, biodiversity and the urban environment. Moreover, the population who lives in those areas is always in danger of flooding.

Subtly, the new law masquerades the intention of promoting deforestation. As an example, it admits the consolidation of other agroforestry activities in rural properties no larger than 4 fiscal modules, located in ridge lines considered by the law APP. Everything duly controlled in compliance with good agronomic and conservation practices of the soil and water according to the decision of the State Environment Councils ${ }^{28}$.

Moreover, the new law allows the practice of aquaculture, in the APP, in rural properties no larger than 15 fiscal modules. The landowners must fulfill the following conditions: $i$ ) adoption of sustainable practices regarding the handling of soil and water and assuring the quality and quantity according to the State Environment Councils; ii) the activity must be in accordance to the basin plans; $i i i$ ) the activity must be authorized by the environmental agency; $i v$ ) the estate must be registered in the Rural Environmental Registry (CAR).

At first, the possibility of keeping an APP with no vegetation in estates with no more than 4 fiscal modules and the authorization to practice aquaculture in APP along river and lake banks seems to benefit small properties. However, this is a mistake. In Brazil, the fiscal module is a measuring unit that varies (from 5 to $110 \mathrm{ha}$ ) from municipality to municipality. If we consider a property measuring $440 \mathrm{ha}$, we are evidently not referring to a small property. Thus, the law is gradually legalizing the destruction of native vegetation, as well as the essential ecological processes, protected by the Constitution.

The National Environment Council (CONAMA) - Ministry of Environment Council, composed by government and society representatives- had power to create new hypothesis in the list of activities (public services and

\footnotetext{
${ }^{27}$ Law No 12.651 , article $8^{\circ}, \$ 2^{\circ}$.

${ }^{28}$ Law No $12.651 / 12$, article $63, \$ 3^{\circ}$.
} 
social interest) that could justify the suppression of vegetation. The new law transferred the responsibility of CONAMA to the Presidency. So, instead of having a full discussion on the various sectors of society regarding the new hypothesis of vegetation removal in APP, a presidential decree can decide this issue, without consulting any other segment ${ }^{29}$.

It is also worth mentioning the possibility of removing vegetation from APP to improve transportation and road system including those necessary for land subdivision, approved by the Municipalities. This practically annuls the protection of urban APP, which today faces many illegal occupations that destroy these protected areas.

\section{Legal Reserve.}

The Legal Reserve is different from APP. It is a portion of properties or possessions in rural estates, that must be kept covered by native vegetation, thus imposing restrictions to the use of this space, with the aim of promoting the sustainable management and protection of biodiversity. This is a way to ensure, in all the biomes, the maintenance of native species and ecosystems that grow there.

The vegetation of a Legal Reserve cannot be suppressed. Under the new law, the function of the legal reserve is to assure the economic use of natural resources in a sustainable way, assist the conservation and rehabilitation of ecological processes and promote conservation of biodiversity, as well as shelter and protection of wildlife fauna and native flora $^{30}$.

The extension of restricted areas, in rural properties or possessions varies according to the region of the country: In the Amazon 80\%; in properties located in rural savannahs in the Amazon 35\%. In this case, at least $20 \%$ must be protected in the property itself and $15 \%$ in the form of compensation in another area, located in the same watershed. In other regions $20 \%^{31}$.

In the former Forest Code, the registration of Legal Reserve was compulsory, setting a certainty in law enforcement, since the registry occurred in an official notary public, not subject to political changes. The new law changed this system of control, sending the registration of rural properties and its legal reserves to the Rural Environmental Registry - CAR, a government data system, still being implemented.

Moreover, the new law allows the computation of app in the calcula-

${ }^{29}$ Law $\mathrm{N}^{\circ} 12.651 / 12$, article $3^{\circ}$, VIII, e e IX, $g$.

${ }^{30} \mathrm{Law} \mathrm{N}^{\circ} 12.651 / 12$, article $3^{\circ}$, III.

${ }^{31}$ Legal Amazon: the States of Acre, Pará, Amazonas, Roraima, Rondônia, Mato Grosso and Amapá and the the States of Tocantins and Goiás, in the regions northern of the parallel $13^{\circ} \mathrm{S}$; and the State of Maranhão in the regions western of the parallel $44^{\circ}$ W. Law No. $12.651 / 12$, article $3^{\circ}$, I and art. 12 , I. 
tion of the percentage of legal reserve of the property under the following conditions: $i$ ) the benefit does not involve the conversion of new areas for alternative land use; $i i)$ the area to be preserved is computed or in recovery, as evidenced by the landlord to the agency member of SISNAMA; iii) the owner or possessor has registered the estate in the Rural Environmental Registry - CAR.

This rule destroys each and every principle contained in the law in favor of biodiversity. The three conditions above highlight the fragility of native forests. In order to include the APP in the calculation of Legal Reserve, by eliminating native forest, we must not only extend the deforestation occurred in the past, but using only what has already been destroyed (without any obligation of recovering). The owner or possessor has to prove to the environmental agency that the area is preserved or under recovery, which is fairly easy, since there is no obligation in recovering any destruction. Furthermore, the third condition refers to the simple law enforcement -to include the estate in the Rural Environmental Registry-CAR, which is already mandatory for all rural estates. Minor details like that, in the law, will cause a significant decrease of native forests in the country, duly authorized.

For Legal Reserve, the date of 7/22/2008 when the Decree No 6.514, imposing heavy fines for environmental law offenders was published, a watershed between legality and illegality was created. The current law requires the immediate suspension of such activities on Legal Reserve deforested from this date on and not before; as if the former Code had no legal force. This amnesty benefits people who disrespected the forest law and opens a serious precedent concerning the way the Brazilian Authorities deal with Nature and its importance.

\section{THE EFFECTS OF THE NEW FOREST LAW ON COMMITMENTS MADE} BY BRAZIL BEFORE THE INTERNATIONAL COMMUNITY

in the Convention on Biological Diversity

Besides confronting the Brazilian Constitution, regarding the right of each and everyone to a balanced environment, and the protection of essential ecological processes, the new law ignores commitments undertaken by Brazil before the International Community, in Convention on Biological Diversity.

Brazil signed the Convention on Biological Diversity (CBD) June $5^{\text {th }}$ 1992 (World Environment Day) and ratified this text on 2-28-1994. Decision X/2 states in its annex the Strategic Plan for Biodiversity 2011-212 ${ }^{32}$

${ }^{32}$ CBD. COP 10 Decision X/2X/2. Strategic Plan for Biodiversity 2011-2020, 
(Decision X/2. Strategic Plan for Biodiversity 2011-2020) and was adopted during COP 10 , setting targets to be achieved by 2012 . Considering that the Law $\mathrm{N}^{\circ} 12.651 / 12$ authorizes deforestation, especially in APP and Legal Reserves, there will be a significant loss of native forest, which compromises the achievement of the some goals.

The Strategic Goal B refers to the reduction of the direct pressures on biodiversity and promote sustainable use. According Target 5, by 2020, the rate of loss of all natural habitats, including forests, is at least halved and where feasible brought close to zero, and degradation and fragmentation is significantly reduced. Although the new law enhances the importance of ecosystems, this instrument is indeed an authorization to promote the destruction of native forests.

Under Target 7, by 2020 areas under agriculture, aquaculture and forestry are managed sustainably, ensuring conservation of biodiversity. If the new law allows deforestation, the biodiversity will be strongly affected by this decision.

In accordance to Target 8 , by 2020 , pollution, including those that come from excessive nutrients, has been brought to levels that are not detrimental to the function of ecosystems and biodiversity. With the increase of cultivated areas, which occupy areas of native vegetation in Brazil, duly authorized by Law $\mathrm{N}^{\circ} 12.651 / 12$, the increasing use of pesticides and fertilizers will not favor the fulfillment of this goal.

The Strategic Goal C refers to the improvement of the status of biodiversity by safeguarding ecosystems, species and genetic diversity. Again, there is no certainty that it is assured.

Target Proposes 12, by 2020, that the extinction of species known Threatened Has Been Prevented and Their conservation status, Particularly of Those most in decline, Has Been improved and sustained. Brazil is a very large country and in many ways still unknown. Not all species found in the biomes are well known nor are cataloged in detail. This means that there is no knowledge of the entire Brazilian biodiversity, which may suffer major losses from deforestation authorized by the new law.

Strategic Goal D requests the enhance of benefits to all from biodiversity and ecosystem services. According to Target 14, by 2020, ecosystems that provide essential services, including services related to water, and contribute to health, livelihoods and well-being, are restored and safeguarded, taking into account the needs of women, indigenous and local communities, and the poor and vulnerable. The new law legalized the destruction of forests,

available at: http://www.cbd.int/decision/cop/?id=12268 [access on 26 of October 2012]. 
including part of APP and Legal Reserves. As a consequence, this destruction will reach ecosystems, and protection of water bodies against siltation and contamination by pesticides and fertilizers, which the riparian forest has the property of retaining will not be assured.

In accordance to Target 15, by 2020, ecosystem resilience and the contribution of biodiversity to carbon stocks has been enhanced, through conservation and restoration, including restoration of at least 15 per cent of degraded ecosystems, thereby contributing to climate change mitigation and adaptation and to combating desertification. With the decrease of vegetation, which is a sink for $\mathrm{CO} 2$, the new law will certainly contribute to the increase of global warming, unlike the established goal.

According UNEP 33 , "as the basis for all ecosystem services, and the foundation for truly sustainable development, biodiversity plays fundamental roles in maintaining and enhancing the well-being of the world's more than 6.7 billion people, rich and poor, rural and urban alike. Biodiversity comprises much of the renewable natural capital on which livelihoods and development are grounded. However, ongoing, and in many cases, accelerating declines and losses in biodiversity over the past 20 years have decreased the capacity of many ecosystems to provide services, and have had profound negative impacts on opportunities for sustainable development around the planet. These impacts are particularly pronounced in the developing world, in large part due to the patterns of consumption and trade in the industrial world, which themselves are not sustainable" 34 . The new forest law ignores the importance of biodiversity as if it had no value for the futures generations. The decisions taken in the new law did not considerate the complexity involved in forest protection.

\section{THE EFFECTS OF THE NEW FOREST LAW ON COMMITMENTS MADE BY BRAZIL}

BEFORE THE INTERNATIONAL COMMUNITY IN THE CCC.

It is known that tropical forests are essential for the maintenance of the conditions of human life on the planet, mainly due to issues related to climate change. If we can not reduce tropical deforestation and conserve large stocks of forests, the climate will enter into very dangerous process instability, where extreme events become more frequent, causing immeasurable environmental damage, large economic losses and jeopardizing human lives.

\footnotetext{
${ }^{33}$ United Nations Environmental Program.

${ }^{34} \mathrm{ONU}$ - UNEP. Global Environment Outlook 4: Environment for Development (2007).
} 
Covering an area of approximately 4.2 million square $\mathrm{km}$, the Amazon ecosystem in Brazil holds the largest block of tropical forest remaining and continues in the world. A veritable storehouse of carbon on the order of 50 billion tones, equivalent to 25 "Kyoto Protocols" obligations satisfied or five years of global emissions of greenhouse gases (GHG).

Little more than $80 \%$ of the planet's tropical forests are preserved, of which 60\% are in Brazil. Cradle of the planetary biodiversity, the Amazon is also a key to balance regional and global climate ${ }^{35}$.

However, in the same way that the new law ignored constitutional protection of the environment and international commitments under the Convention on Biodiversity, there are absolute incoherence of principles between the text of the new Code and the National Policy on Climate Change (NPCC), as well as plan its goals for reducing GHG emissions.

In this sense, the new Forest Act conflict with the provisions of Law $\mathrm{N}^{\circ} 12.187$ of 29 December 2009, which established the NPCC, insofar as its principles, goals, and instruments do not comply with those principles, objectives, and instruments of the NPCC. In other words, while the NPCC aims to integrate all applicable action plans for prevention and control of deforestation in the Brazilian biomes, the new law ignores them and does not consider its potential capacity of mitigation and adaptation to climate change. Remember that deforestation is still the "Achilles heel" of the country, as the country is the fourth global emitter of GHG.

So, the occupation of new areas and reforestation planned layoffs in the new law will not be able to limit the expansion of the agricultural frontier and can consolidate historical systems of agricultural production, with high environmental impact, especially in the case of livestock farming, low profitability.

While Article 2 of NPCC provides the implementation of measures to reduce emissions of greenhouse gases and increase sinks, the text of the new law waiver properties of up to four fiscal modules of the need to rebuild the areas of Legal Reserve used and authorizes who deforested before the increase in the percentage of legal reserve (from 2000) to keep only the area required by the legislation of the time.

The same way the cited Plans of Action for the Prevention and Control of Deforestation in the biomes, referred to in art. 6, which turn out to be one of the main instruments of the National Policy on Climate Change, were not considered when the legalization of intervention or vegetation removal in APPs and maintenance activities consolidated in cases of public

${ }^{35}$ Malhi, Y. and others, Climate Change, Deforestation and the Fate of the Amazon, in Science, 319 (2008), pp. 169-172. 
utility or social interest, low environmental impact provided for in the new law, as well as other activities considered.

Our legislators have ignored the section II of Article 3 of the Law of NPCC, by not establishing measures in the new law to minimize the identified causes of climate change with an anthropogenic origin use and occupation in productive areas, despite the consensus among the scientific and technicians engaged in the study of the phenomena involved, widely disseminated by the Brazilian Society of Advancement of Science (SBPC) ${ }^{36}$.

So, once again, Congress preferred to consider whether there is a false contest between agriculture and the environment. Despite technical studies from the federal government about the proper management and conservation of soil and water against a backdrop of environmental change ${ }^{37}$ that ensure the highest productivity of the field without the need to advance the agricultural frontier, our parliamentarians abandoned the path of consensus and seem to overlook that agriculture and livestock depend on the balance of the environment, the conditions of soil, water, regular rainfall, etc. ${ }^{38}$.

Apparently they had seen unaware that the sustainability of the agricultural sector is essential for the inclusion of our products in the international market.

As the scientific community warns ${ }^{39}$, this combination of deforestation in the Amazon region with global warming could bring to the region strong droughts in the future, with reductions in the volume of rain of 20 to $30 \%$ culminating in a process of forest degradation, currently better known for "savannization" 40 , which will have an impact socioeconomic incalculable, especially for agricultural production in areas already deforested.

${ }^{36}$ SBPC and ABC Manifestates Before President Dilma, available in: http://www. sbpcnet.org.br/site/home/home.php?id=1766 [access on 1 of April 2013].

${ }^{37}$ Prado, R. B. - Turetta, A. P. D. - Andrade, A. G. de, Manejo e conservação do solo e da água no contexto das mudanças ambientais (Rio de Janeiro, Embrapa Solos, 2010), pp. 25-40.

${ }^{38}$ Reforma do Código Florestal: qual o caminho para o consenso? Contribuiçóes para o Relatório da Comissáo de Meio Ambiente do Senado Federal sobre a reforma do Código Florestal Brasileiro. (Brasília, Instituto de Pesquisa Ambiental da Amazônia, 2011)

${ }^{39}$ SBPC., cit. (n. 36); MALHi and others, cit. (n. 36); Nobre, C. A. - Sellers, P. J. - Shukla, J., Amazonian Deforestation and Regional Climate Change, in Journal of Climate, 4 (1991), pp. 957-988; Hansen, J. - M. SATo - Ruedy, R. - Lo, K. - Lea, D. W. - Medina-Elizade, M., Global Temperature Change, in Proceedings of the National Academy of Sciences of the United States of America, 103 (2006), pp. 14288-14293; Oyama, M. D. - Nobre, C. A., A New Climate-Vegetation Equilibrium State for Tropical South America, in Geophysics Research Letters, 30 (2003), p. 2199.

${ }^{40}$ MalHi and others, cit. (n. 36); Nepstad, D. and others, The End of Deforestation in the Brazilian Amazon, in Science, 326 (2009), pp. 1350-1351. 
Despite recent data on the quality of implementation of forest management in Pará recognizing a reduction of deforestation in the Amazon region $^{41}$, the gaps left by the new Forest Act, federal an d private investments in infrastructure induce deforestation and the inevitable recovery in prices of meat and soy in the international market continue to pressure the forest ${ }^{42}$.

After all, the agricultural sector plans to double its production by 2020 , both agricultural and livestock ${ }^{43}$, threatening, with support in the new law, the objectives of NPCC.

\section{VII. "RIo + 20"}

The discussions held in 2012 in the city of Rio de Janeiro, at the United Nations Conference on Sustainable Development, called "Rio + 20", resulted in the document "The Future We Want" which highlights, among other topics, "the social, economic and environmental aspects of forests for people", and participating countries support all efforts to reduce and reverse deforestation and forest degradation ${ }^{44}$. Moreover, countries highlight the initiatives to reduce emissions of greenhouse gases from deforestation and forest degradation in developing countries and the role of forest conservation to increase the storage of carbon stocks in forests in developing countries.

The Declaration of "Rio +20 " reaffirm the necessity to promote, enhance and support more sustainable agriculture, including crops, livestock, forestry, fisheries and aquaculture, that improves food security, eradicates hunger and is economically viable, while conserving land, water, plant and animal genetic resources, biodiversity and ecosystems and enhancing resilience to climate change and natural disasters. This document recognizes the need to maintain natural ecological processes that support food production systems ${ }^{45}$.

It is true that Law $\mathrm{N}^{\circ} 12.651 / 12$ provides support programs and incentives for preservation and restoration of the environment. In this sense, it refers to the payment or incentive for environmental services, as well as

${ }^{41}$ Monteiro, A. and others, Boletim Transparência Manejo Florestal Estado do Pará (2010-2011) (Belém, Imazon, 2012), p. 16.

${ }^{42}$ Soares Filmo, B. and others, The Role of Brazilian Amazon Protected Areas in Climate Change Mitigation (PNAS, 2010); MoutinHo, P. and others, REDD no Brasil: um enfoque amazônico: fundamentos, critérios e estruturas institucionais para um regime nacional de Redução de Emissões por Desmatamento e Degradação Florestal (Instituto de Pesquisa Ambiental da Amazônia, 2011), p. 147.

${ }^{43}$ Brasil, Ministério da Agricultura, Pecuária e Abastecimento, Plano Agrícola e Pecuário 2011-2012 (Secretaria de Política Agrícola, Brasília, 2011) Mapa/SPA.

${ }^{44}$ United Nations Conference on Sustainable Development, The Future We Want, A/CONF./216/L.1., 193, p. 37.

${ }^{45}$ Ibíd., p. 37. 
compensation for environmental conservation measures required to fulfill the objectives of the Law. But still, authorization to deforestation of areas that were legally protected in the past, has increased considerably.

\section{CONCLUSION}

The issue regarding the use of rural land in Brazil has never been mellow. Since colonial times, when Portugal granted estates to Portuguese citizens (the Hereditary Captaincies) the relation between the owner or possessor and the land is unlimited. Any Governmental intervention has always involved resistance: in compliance with the law, or in resilience by the Authorities. The former Forest Code is an example of this statement. It introduced limitations to the exercise of property without ever being fully obeyed, plus it frequently received anointment from the Authorities.

This model, perpetuated in Brazil, still goes on and tends to drive the country to a situation where the soil, water, and biodiversity have continuously been destroyed, simply because a few people wish to expand their areas of grain crops and cattle ranching. However, all these changes will not represent a socially relevant benefit to local populations. Regarding sugarcane, the situation of workers in this sector is of extreme poverty. For soybeans, mechanized farming eliminates the local workforce and the population is forced to seek shelter in cities. Currently, $84 \%$ of the Brazilian population lives in urban centers ${ }^{46}$, which is in part a result of the lack of a public policy for people who live in the countryside.

The new Brazilian forest law legalizes the destruction of a significant portion of the existing native vegetation in the APP and Legal Reserves, in the name of food production. This, however, hides another purpose: to earn profits in the production of commodities.

Furthermore, the most serious issue in this law, is how it was made up. At first, one gets the impression that finally Brazil will have a clear policy regarding the use and protection of forests, soil and water. However, the real purposes that led Congress to vote this new law come up when the details and administrative procedures are carefully analyzed.

The law authorizes the exchange of native forest for other activities in various situations. However, it always imposes conditions such as to observe the best planting techniques, or not to replace the native forest for other vegetation. All these responsibilities are delegated to environmental

${ }^{46}$ IBGE: Census 2010: Brazil's population is 190,732,694 people. Available at: http://www.ibge.gov.br/home/presidencia/noticias/noticia_visualiza.php?id_ noticia $=1766$ [access on 26 of October 2012]. 
agencies in charge of monitoring and controlling the human activities in these areas. In a country measuring $8,514,876,599$ square $\mathrm{km}^{47}$, where the culture continues to be "conquering" the land it will be very difficult to enforce the new law.

In some cases, the effectiveness of law depends entirely on an impeccable performance of Authorities in the supervision and control. Although the current government may have good intentions in law enforcement, we cannot guarantee that, in the future, the institutional model aimed at protecting forests will be disarticulated.

Although the law has been approved in accordance with all constitutional procedures, the Brazilian population was barely consulted and the majority of the people remain unaware today, was unaware of the situation of native forests and the impact of the new rules in Brazilian biodiversity.

It is legal, but not legitimized. Unless a minority interested in their own production and profit, most Brazilians ignore the effects of this complex, long and absurd law that authorizes and legalizes deforestation and biodiversity destruction.

The destruction of part of APP and Legal Reserve, in order to facilitate the development of small farms, will not be useful as well if associated with it, if there is no serious policy to developed an sustainable agricultural technology, adapted to the various regions and biomes in the Country, associated with formulas that facilitate the marketing of products.

Brazil, with its new forest law, trails a path in the opposite direction of its own History, and might be too late when these effects are finally detected.

\section{BIBLIOGRAFÍA}

Benjamin, Antonio Herman Vasconcelos, in Environmental Damage: Prevention, Recovery e Repression (São Paulo, Revista dos Tribunais, 1993).

Convention on Biological Diversity, COP 10 Decision X/2X/2. Strategic Plan for Biodiversity 2011-2020, available at: http://www.cbd.int/decision/cop/?id=12268.

Conservation of Living Resources for Sustainable Development (São Paulo, CESP, 1984).

Granziera, Maria Luiza Machado, Environmental Law (2 ${ }^{\text {nd }}$ edition, São Paulo, Atlas, 2011).

Hansen, J. and others, Global temperature change, in Proceedings of the National Academy of Sciences of the United States of America, 103 (2006).

IBAMA, Biomas brasileiros. Amazônia, available in: http://www.ibama.gov.br/ecossistemas/amazonia.htm.

${ }^{47}$ IBGE, Área Territorial Oficial. Available at: http://www.ibge.gov.br/home/geociencias/cartografia/default_territ_area.shtm [access on 22 of October 2012]. 
IBGE Releases Map of Biomes of Brazil and the Vegetation Map of Brazil, to celebrate World Biodiversity Day, available in: http://www.ibge.gov.br/home/presidencia/ noticias/noticia_visualiza.php?id_noticia $=169$.

IBGE, Census 2010: Brazil'spopulation is 190,732,694 people, available in: http://www. ibge.gov.br/home/presidencia/noticias/noticia_visualiza.php?id_noticia $=1766$.

IBGE. Área Territorial Oficial, Environmental Law in: http://www.ibge.gov.br/home/ geociencias/cartografia/default_territ_area.shtm.

Reforma do Código Florestal: qual o caminho para o consenso? Contribuiçóes para o Relatório da Comissão de Meio Ambiente do Senado Federal sobre a reforma do Código Florestal Brasileiro (Brasília, Instituto de Pesquisa Ambiental da Amazônia, 2011).

Magalhães, Vladimir Garcia, The Forest Code and the Global Warming, in Lavratti, Paula - Buzelato Prestes, Vanêsca, Law and Climate Changes, Forest Code Revision: Juridical Limitations (São Paulo, Instituto o Direito por um Planeta Verde, 2010, available in: http://www.observatorioeco.com.br/wp-content/uploads/ up/2010/12/cadigo-florestal.pdf.

Malmi, Y. and others, Climate Change, Deforestation and the Fate of the Amazon, in Science 319 (2008).

Ministério da Agricultura, Pecuária e Abastecimento, Plano Agrícola e Pecuário 20112012 (Secretaria de Política Agrícola, Brasília, 2011, Mapa/SPA).

Monteiro, A. and others, Boletim Transparência Manejo Florestal Estado do Pará (2010-2011) (Belém, Imazon, 2012).

Moreira, Iara Verocai Dias, Environmental Vocabulary (Rio de Janeiro, Fundação Estadual de Engenharia do Meio Ambiente, 1990).

Moutinho, P. and others, REDD no Brasil: um enfoque amazônico: fundamentos, critérios e estruturas institucionais para um regime nacional de Redução de Emissões por Desmatamento e Degradação Florestal (Instituto de Pesquisa Ambiental da Amazônia, 2011).

Nepstad, D. and others, The End of Deforestation in the Brazilian Amazon, in Science 326 (2009).

Nobre, C. A. and others, Amazonian Deforestation and Regional Climate Change, in Journal of Climate, 4 (1991).

O Código Florestal e a Ciência: Contribuições para o Diálogo (São Paulo, Sociedade Brasileira Para o Progresso da Ciência - Academia Brasileira de Ciências, 2011).

Oyama, M. D. - Nobre, C. A., A New Climate-Vegetation Equilibrium State for Tropical South America, in Geophysics Research Letters, 30 (2003).

Prado, R. B. - Turetta, A. P. D. - Andrade, A. G. de, Manejo e conservação do solo e da água no contexto das mudanças ambientais (Rio de Janeiro, Embrapa Solos, 2010)-

SBPC and ABC manifestates before President Dilma, available in: http://www.sbpcnet. org.br/site/home/home.php?id=1766.

SoAres-Filho, B. and others, The Role of Brazilian Amazon Protected Areas in Climate Change Mitigation (PNAS, 2010).

United Nations Conference on Sustainable Development, The Future We Want (A/ CONF./216/L.1., 193). 